\title{
Antimalarial Compounds from the Root Bark of Garcinia polyantha Olv.
}

\author{
Alain Meli Lannang, Gabin Nselapi Louh, David Lontsi, Sabine Specht, \\ Salem Ramadan Sarite, Ulrich Flörke, Hidayat Hussain, Achim Hoerauf, \\ Karsten Krohn
}

Received: May 2, 2008 / Accepted: August 5, 2008

(C) Japan Antibiotics Research Association

\begin{abstract}
Eight compounds were isolated from the roots of Garcinia polyantha, and identified. Two of them, the xanthone garciniaxanthone I (1), and the triterpene, named garcinane (2), are reported as new natural products. The structures of the new compounds were elucidated on the basis of $1 \mathrm{D}$ and 2D NMR spectroscopic studies. The structure of compound $\mathbf{1}$ was confirmed by Xray crystallography. Among the remaining six known compounds, three were known xanthones [smeathxanthone A (3), smeathxanthone B (4), and chefouxanthone (5)], one benzophenone [isoxanthochymol (6)], one triterpene [magnificol], and one sterol [ $\beta$-sitosterol]. The in vitro antimalarial activity of isoxanthochymol (6) against Plasmodium falciparum shows strong chemosuppression of parasitic growth.
\end{abstract}

Keywords Garcinia polyantha, garciniaxanthone I, Xray crystallography, xanthones; antimalarial activity

\section{Introduction}

The genus Garcinia of the Guttiferae family is well known to be a rich source of bioactive prenylated xanthones [1 3], triterpenes [4], and benzophenones [5, 6]. In continuation of our search for bioactive substances from
African medicinal plants, we investigated the methanol extract of the root bark of Garcinia polyantha, a tree distributed in the lowland tropical rainforest of West, East and Central Africa [7, 8]. In the current investigation we focused on minor constituents from G. polyantha, and one new xanthone (1), one new triterpene (2), and six known compounds (3 $\sim \mathbf{6}$, magnificol, and $\beta$-sitosterol), were isolated (Fig. 1). We report herein the structure elucidation of the eight natural products and their antimalarial activity.

\section{Materials and Methods}

\section{General Experimental Procedures}

Melting points were determined on a Büchi SMP-20 melting point apparatus and are uncorrected. UV spectra were measured with a UV-210 PC UV. IR spectra were recorded on a SHIMADZU FTIR-8400S spectrometer in $\mathrm{KBr}$ disks. EI-MS (ionization voltage $70 \mathrm{eV}$ ) and HR-EIMS mass spectra were recorded on Finnigan MAT double focusing spectrometer Model $8230 .{ }^{1} \mathrm{H}-$ and ${ }^{13} \mathrm{C}-\mathrm{NMR}$ spectra were recorded with a Bruker Avance $500 \mathrm{MHz}$ NMR spectrometer in $\mathrm{CDCl}_{3}$ or $\mathrm{CDCl}_{3} / \mathrm{CD}_{3} \mathrm{OD}$. Chemical shifts are recorded relative to TMS $(\delta=0)$ internal standard and coupling constants $J$ are reported in Hz. Optical rotation were recorded with a Perkin-Elmer 241
K. Krohn (Corresponding author), U. Flörke, H. Hussain: Department of Chemistry, Universität Paderborn, Warburger Straße 100, 33098 Paderborn, Germany, E-mail: k.krohn@upb.de A. M. Lannang, G. N. Louh, D. Lontsi: Department of Organic Chemistry, University of Yaoundé I, P.O. Box 812 Yaoundé, Cameroon
S. Specht, S. R. Sarite, A. Hoerauf: Institute of Medical Microbiology, Immunology and Parasitology, University Hospital Bonn, Sigmund Freud Str. 25, 53105 Bonn, Germany 


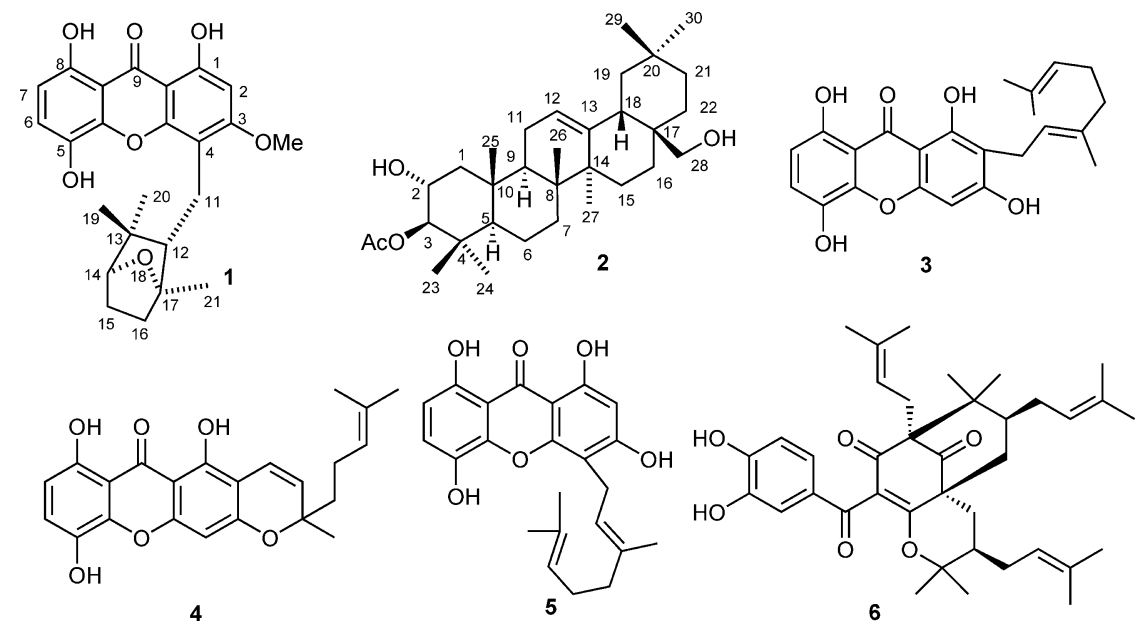

Fig. 1 Structures of compounds $\mathbf{1} \sim \mathbf{6}$ isolated from Garcinia polyantha.

polarimeter. Column chromatography (CC) was carried out on silica gel $60 \mathrm{~F}_{254}$ (Merck) and silica 100 respectively. Precoated plates of silica gel $60 \mathrm{GF}_{254}$ were used for analytical purposes and the spots were detected with a UV lamp at 254 and $366 \mathrm{~nm}$ and by spraying with $50 \% \mathrm{H}_{2} \mathrm{SO}_{4}$ or ceric sulfate followed by heating.

\section{Plant Material}

The roots of Garcinia polyantha were collected at Mt Kala, Central Province, Cameroon in August 2003, and identified by Mr. Nana Victor of the Cameroon National Herbarium (Yaoundé), where a voucher specimen (21337/SRF/ Cam/Mt Kala) was deposited.

\section{Extraction and Isolation}

Air dried root bark of $G$. polyantha $(5.2 \mathrm{~kg})$ was extracted with $\mathrm{MeOH}$ at room temperature for two days. The extract was concentrated at reduced pressure to yield $100 \mathrm{~g}$ of crude extract. The methanolic extract was first subjected to silica gel flash chromatography, eluting with hexaneEtOAc of increasing polarity to afford fractions $(A \sim D)$ and pure chefouxanthone $(\mathbf{5}, 73 \mathrm{mg})$ and isoxanthochymol (6, $1.2 \mathrm{~g})$. Fractions A and B (2.3 g) were purified on a silica gel column with hexane-EtOAc with increasing order of polarity to yield magnificol (46 mg) and smeathxanthone B (4, $31 \mathrm{mg})$, respectively. Similarly, fraction C (5.4 g) was subjected to column chromatography (silica gel) eluting with hexane-EtOAc with increasing polarity to yield smeathxanthone A $(\mathbf{3}, 22 \mathrm{mg})$ and subfractions $\mathrm{C}_{1}$ and $\mathrm{C}_{2}$. Subfraction $\mathrm{C}_{1}(1.1 \mathrm{~g})$ was further purified by column chromatography (silica gel) eluting with hexane - EtOAc to give garciniaxanthone $\mathrm{I}(\mathbf{1}, 11 \mathrm{mg})$. Finally, subfraction $\mathrm{C}_{2}$ $(1.7 \mathrm{~g})$ was chromatographed (silica gel) with hexane -
EtOAc $(7.8: 2.2)$ yielding garcinane $(2,15 \mathrm{mg})$ and $\beta$ sitosterol $(28 \mathrm{mg})$.

\section{Garciniaxanthone I (1)}

Yellow crystals; mp $254 \sim 256^{\circ} \mathrm{C} ;[\alpha]_{\mathrm{D}}^{20}-37.5$ (c 0.8 , $\left.\mathrm{CHCl}_{3}+10 \% \mathrm{MeOH}\right) ; \mathrm{UV}(\mathrm{MeOH}) \lambda_{\max }(\log \varepsilon): 205$ (3.03), 220 (3.04), 297 (2.50), 337 (4.28), 335 (3.89); IR $(\mathrm{KBr}) \quad v_{\max }: 3460,3360,1660,1627 \mathrm{~cm}^{-1}$; ${ }^{1} \mathrm{H}-\mathrm{NMR}$ $\left(\mathrm{CDCl}_{3}, 500 \mathrm{MHz}\right) \delta 12.30(1 \mathrm{H}, \mathrm{s}, 1-\mathrm{OH}), 11.33(1 \mathrm{H}, \mathrm{s}, 9-$ $\mathrm{OH}), 8.62(1 \mathrm{H}, \mathrm{s}, 5-\mathrm{OH}), 7.24(1 \mathrm{H}, \mathrm{d}, J=8.8 \mathrm{~Hz}, \mathrm{H}-6), 6.66$ $(1 \mathrm{H}, \mathrm{d}, J=8.8 \mathrm{~Hz}, \mathrm{H}-7), 6.38(1 \mathrm{H}, \mathrm{s}, \mathrm{H}-2), 3.80(1 \mathrm{H}, \mathrm{d}$, $J=4.9 \mathrm{~Hz}, \mathrm{H}-14), 3.90\left(3 \mathrm{H}, \mathrm{s}, \mathrm{OCH}_{3}\right), 2.85(1 \mathrm{H}, \mathrm{dd}$, $J=14.5,8.8 \mathrm{~Hz}, \mathrm{H}-11 \mathrm{a}), 2.74(1 \mathrm{H}, \mathrm{dd}, J=14.5,6.8 \mathrm{~Hz}, \mathrm{H}-$ $11 \mathrm{~b}), 2.20$ (1H, dd, $J=8.8,6.8 \mathrm{~Hz}, \mathrm{H}-12), 1.94$ (1H, m, H15a), 1.68 (1H, m, H-15b), 1.53 (1H, m, H-16a), 1.44 (1H, m, H-16b), 1.27 (1H, s, H-21), 1.03 (1H, s, H-19), 0.97 (1H, s, H-20); ${ }^{13} \mathrm{C}-\mathrm{NMR}\left(\mathrm{CDCl}_{3}, 125 \mathrm{MHz}\right) \delta 185.1$ (C-9), 165.2 (C-3), 161.5 (C-1), 153.7 (C-8), 153.4 (C-4a), 143.7 (10a), 136.4 (C-5), 124.8 (C-6), 109.9 (C-7), 108.3 (C-8a), 107.2 (C-4), 103.3 (C-9a), 96.4 (C-2), 87.7 (C-17), 86.9 (C14), $55.9\left(\mathrm{OCH}_{3}\right), 53.6(\mathrm{C}-12), 45.9(\mathrm{C}-13), 38.5$ (C-16), 26.1 (C-15), 26.1 (C-20), 23.1 (C-19), 21.1 (C-11), 18.0 (C-21); EI-MS m/z (rel. int.): 426 [M $\left.{ }^{+}\right](22), 408$ (4), 341 (6), 315 (18), 287 (100), 274 (16), 257 (35), 97(19); 44 (24); HREI-MS $m / z 436.1686$ (calcd. for $\mathrm{C}_{24} \mathrm{H}_{26} \mathrm{O}_{7}$, 436.1679).

\section{Garcinane (2)}

White powder; mp $235 \sim 237^{\circ} \mathrm{C} ;[\alpha]_{\mathrm{D}}^{20}+80$ (c 0.25 , $\mathrm{CH}_{2} \mathrm{Cl}_{2}$ ); IR (KBr) $v_{\max } 3730,3460,1660,1627 \mathrm{~cm}^{-1} ;{ }^{1} \mathrm{H}-$ NMR $\left(\mathrm{CDCl}_{3}, 500 \mathrm{MHz}\right) \delta 5.20(1 \mathrm{H}, \mathrm{t}, J=4.0 \mathrm{~Hz}, \mathrm{H}-12)$, $4.51(1 \mathrm{H}, \mathrm{d}, J=10.0 \mathrm{~Hz}, \mathrm{H}-3), 3.80$ (1H, ddd, $J=12.5,10.0$, $4.5 \mathrm{~Hz}, \mathrm{H}-2), 3.53$ (1H, d, $J=10.0 \mathrm{~Hz}, \mathrm{H}-28 \mathrm{a}), 3.22(1 \mathrm{H}, \mathrm{d}$, 
$J=10.0 \mathrm{~Hz}, \mathrm{H}-28 \mathrm{~b}), 2.14$ (1H, s, $\left.\mathrm{CH}_{3} \mathrm{COO}\right), 2.07$ (1H, dd, $J=12.5,4.5 \mathrm{~Hz}, \mathrm{H}-1 \mathrm{a}), 2.00$ (1H, dd, $J=14.0,5.0, \mathrm{H}-18)$, 1.90 (1H, m, H-16a), 1.90 (1H, m, H-11), 1.90 (1H, m, H16b), $1.63(1 \mathrm{H}, \mathrm{dd}, J=11.0,7.8 \mathrm{~Hz}, \mathrm{H}-9), 1.63(1 \mathrm{H}, \mathrm{dd}$, $J=11.0,5.0 \mathrm{~Hz}, \mathrm{H}-19 \mathrm{a}), 1.54$ (1H, m, H-6a), 1.54 (1H, m, H-7a), 1.54 (1H, br dd, $J=14.0,4.0 \mathrm{~Hz}, \mathrm{H}-22 \mathrm{a}), 1.41(1 \mathrm{H}$, m, H-6b), 1.36 (1H, br dd, $J=14.0,3.0 \mathrm{~Hz}, \mathrm{H}-22 \mathrm{~b}), 1.34$ (1H, m, H-7b), 1.31 (1H, brdd, $J=14.0,4.0 \mathrm{~Hz}, \mathrm{H}-21 \mathrm{a})$, $1.19(1 \mathrm{H}$, br dd, $J=14.0,3.0 \mathrm{~Hz}, \mathrm{H}-21 \mathrm{~b}), 1.16(1 \mathrm{H}, \mathrm{s}, \mathrm{H}-$ 27), 1.09 (1H, dd, $J=14.0,11.0 \mathrm{~Hz}, \mathrm{H}-19 \mathrm{~b}), 1.06$ (1H, m, H-15a), 1.01 (1H, s, H-25), 0.98 (1H, m, H-1b), 0.98 (1H, m, H-15b), 0.94 (1H, s, H-30), 0.93 (1H, brt, J=2.0, H-5), 0.90 (1H, s, H-24), 0.89 (1H, s, H-23), 0.88 (1H, s, H-29), $0.87(1 \mathrm{H}, \mathrm{s}, \mathrm{H}-26) ;{ }^{13} \mathrm{C}-\mathrm{NMR}\left(\mathrm{CDCl}_{3}, 125 \mathrm{MHz}\right) \delta 172.4$ $\left(\mathrm{CH}_{3} \mathrm{CO}_{2}\right), 144.3(\mathrm{C}-13), 122.1(\mathrm{C}-12), 84.9(\mathrm{C}-3), 69.7(\mathrm{C}-$ 28), 67.6 (C-2), 55.1 (C-5), 47.9 (C-1), 47.5 (C-9), 46.4 (C19), 42.3 (C-18), 41.8 (C-14), 39.9 (C-8), 38.1 (C-4), 38.0 (C-10), 36.9 (C-17), 34.1 (H-21), 33.1 (C-29), 32.4 (C-7), 31.0 (C-22), 30.9 (C-20), 28.5 (C-23), 25.9 (C-27), 23.5 (C-30), $21.0\left(\mathrm{CH}_{3} \mathrm{CO}_{2}\right), 18.3(\mathrm{C}-6), 25.5(\mathrm{C}-15), 23.6(\mathrm{C}-$ 11), 22.0 (C-16), 16.7 (C-26), 17.6 (C-24), 16.6 (C-25); EIMS $m / z$ (rel. int.): $500\left[\mathrm{M}^{+}\right]$(4); 470 (72), 234 (79), 203 (100), 189 (61), 119 (56), 69 (51), 43 (59); HREI-MS m/z 500.3869 (calcd. for $\mathrm{C}_{32} \mathrm{H}_{52} \mathrm{O}_{4}, 500.3866$ ).

\section{X-Ray Crystal Structure Analysis of Garciniaxanthone}

\section{I (1)}

$\mathrm{C}_{24} \mathrm{H}_{26} \mathrm{O}_{7} \quad(M \mathrm{r}=426.45)$, orthorhombic, space group $P 2{ }_{1} 2_{1} 2_{1} \quad$ with $a=7.0837(18) \AA, \quad b=13.148(3) \AA, \quad c=$ 21.674(6) $\AA, V=2018.6(9) \AA^{3}, Z=4, D_{\text {calcd }}=1.403 \mathrm{~g} / \mathrm{cm}^{3}$, $\lambda=0.71073 \AA$. Yellow prismatic crystal, size $0.20 \times$ $0.08 \times 0.04 \mathrm{~mm}$. Intensity data were measured on a BrukerAXS SMART APEX CCD diffractometer. A total of 18152 reflections were collected to a maximum $2 \Theta$ value of $55.7^{\circ}$ at $120(2) \mathrm{K}$. Data reduction and semi-empirical absorption correction from equivalents with the Bruker package [9]. The structure was solved by direct methods and refined by full matrix least-squares procedure [10]. The title compound crystallizes in the non-centrosymmetric space group $P 22_{1} 2_{1} 2_{1}$; however, in the absence of significant anomalous scattering effects, the Flack parameter is essentially meaningless. Accordingly, Friedel pairs were merged. All non-hydrogen atoms were given anisotropic thermal parameters; hydrogen atoms were located from difference Fourier maps and refined at idealized positions riding on their parent atoms. The refinement converged at $R 1(\mathrm{I}>2 \sigma(\mathrm{I}))=0.057, \quad w R 2 \quad($ all data $)=0.087$ for 2764 independent reflections and 284 variables. Crystallographic data for the structure of $\mathbf{1}$ have been deposited with the Cambridge Crystallographic Data Center, deposition No. CCDC-680049. Data can be obtained free of charge from The Cambridge Crystallographic Data Centre via www.ccdc.cam.ac.uk/data_request/cif.

\section{Antimalarial Test}

Compounds 1 $\sim \mathbf{6}$ were dissolved in water+DMSO $0.02 \%$ $\mathrm{v} / \mathrm{v}$ [11]. The compounds were administered over a period of four days to the culture and the number of parasites was determined daily. Control experiments were performed either without treatment or with administration of $0.032 \mu \mathrm{M}$ chloroquine in the same solvent.

\section{Culturing of Plasmodium falciparum NF54 Strain}

Plasmodium falciparum isolate NF54 was maintained in small Petri dishes $(5.0 \mathrm{~cm})$ according to a protocol from Moloney [12] and Trager [13] in a gaseous phase of $90 \%$ $\mathrm{N}_{2}, 5.0 \% \mathrm{CO}_{2}$ and $5.0 \% \mathrm{O}_{2}$. Parasites were cultured in human erythrocytes (blood group $\mathrm{A}^{+}$) in RPM1640 medium (Sigma) supplemented with $25 \mu \mathrm{M}$ HEPES, $20 \mathrm{mM}$ sodium bicarbonate, and $10 \%$ heat inactivated human $\mathrm{A}+$ plasma at $10 \%(\mathrm{v} / \mathrm{v})$ hematocrit. The parasitemia of infected erythrocytes was determined by light microscopy and estimated by Giemsa-stained smears. Parasitemia detected in the cultures was scored visually with a 100 -fold oil immersion objective, counting at least 1000 infected erythrocytes to determine the parasitemia.

\section{Inhibitor Experiments by Monitoring Multiplication and Growth of Plasmodia}

Cultures were adjusted to a parasitemia of $0.5 \%$. Aliquots were diluted $1: 10$-fold in RPMI-medium, dispensed into 12-well microculture trays and incubated at $37^{\circ} \mathrm{C}$ in a candle jar. Thereafter, growth medium was changed once a day for four days and inhibitors were added to the media in a concentration of $10 \mu \mathrm{M}$ as indicated. Each substance was analyzed in four independent wells of the microculture tray. Parasitemia was estimated as triplicates daily in each of the four independent wells from Giemsa-stained smears by counting 1000 erythrocytes. To determine the $\mathrm{IC}_{50}$ values, we performed growth experiments with $10 \mu \mathrm{M}, 5.0 \mu \mathrm{M}$ and $2.5 \mu \mathrm{M}$ of each compound. The data obtained in these experiments were computed into plots with linear regression analysis from $y$ axis (inhibition \%) to $x$ axis (inhibitor concentration in $\mu \mathrm{M}$ ) [14].

\section{Results and Discussion}

\section{Physico-chemical Properties}

The physico-chemical properties of garciniaxanthone I (1) and garcinane (2) are summarized in Experimental section. Compound 1, garciniaxanthone I, was obtained as yellow 
crystals reacting positively with $\mathrm{FeCl}_{3}$, suggesting its phenolic nature. The $[\mathrm{M}]^{+}$at $\mathrm{m} / \mathrm{z} 426.1686$ in the HREIMS corresponded to the molecular formula $\mathrm{C}_{24} \mathrm{H}_{26} \mathrm{O}_{7}$. The UV spectrum showed absorption bands at $\lambda_{\max } 335,297$, and $205 \mathrm{~nm}$, indicating the presence of a $1,3,5,8-$ oxygenated xanthone nucleus [3]. The absorption bands at 3460,1660 , and $1627 \mathrm{~cm}^{-1}$ in the IR spectrum suggested a xanthone skeleton with a chelated hydroxyl group [15].

Similarly, garcinane (2) was obtained as a white powder, mp $235 \sim 237^{\circ} \mathrm{C},[\alpha]_{\mathrm{D}}^{20}+80\left(c 0.25, \mathrm{CH}_{2} \mathrm{Cl}_{2}\right)$, and reacted positive in the Lieberman Burchard test for triterpenoids. The molecular formula was deduced as $\mathrm{C}_{32} \mathrm{H}_{52} \mathrm{O}_{4}$ through HREI-MS which showed the $\mathrm{M}^{+}$peak at $\mathrm{m} / z 500.3869$ (calcd. for $\mathrm{C}_{32} \mathrm{H}_{52} \mathrm{O}_{4}, 500.3866$ ). The IR spectrum showed absorption bands for hydroxyl groups at $3730 \mathrm{~cm}^{-1}$ and a double bond at $1627 \mathrm{~cm}^{-1}$.

\section{Structure Elucidation}

Inspection of a part of the ${ }^{1} \mathrm{H}-\mathrm{NMR}$ spectrum (see Experimental) of garciniaxanthone I (1) showed an AB spin system for aromatic type protons at $\delta 7.24(1 \mathrm{H}, \mathrm{d}$, $J=8.8 \mathrm{~Hz}, \mathrm{H}-6)$ and $6.66(1 \mathrm{H}, \mathrm{d}, J=8.8 \mathrm{~Hz}, \mathrm{H}-7)$, typical for the presence of ortho protons. A shielded isolated proton at $\delta 6.38(1 \mathrm{H}, \mathrm{s}, \mathrm{H}-2)$ was in agreement with a pentasubstituted aromatic ring (ring A), and the presence of a methoxy group was evidenced from the three proton singlet at $\delta 3.90$. The signal at $\delta 185.5(\mathrm{C}-9)$ in the ${ }^{13} \mathrm{C}$ NMR and signals at $\delta 12.30(1 \mathrm{H}, \mathrm{s}, 1-\mathrm{OH})$ and $11.33(1 \mathrm{H}$, $\mathrm{s}, 8-\mathrm{OH})$ in the ${ }^{1} \mathrm{H}-\mathrm{NMR}$ spectrum indicated the presence of a conjugated carbonyl and two chelated hydroxyl groups. A free hydroxyl group is suggested by the signal at $\delta 8.62$ $(1 \mathrm{H}, \mathrm{s}, 5-\mathrm{OH})$. The ${ }^{13} \mathrm{C}-\mathrm{NMR}$ spectrum (see Experimental) showed 24 signals, which could be attributed to four $\mathrm{CH}_{3}$, three $\mathrm{CH}_{2}$, five $\mathrm{CH}$, and twelve quaternary carbons including seven oxygenated carbons, as evidenced by the respective DEPT spectra. The long range correlation (Fig. 2) between $\delta 12.30(1-\mathrm{OH})$ with $\mathrm{C}-1, \mathrm{C}-2$, and $\mathrm{C}-9 \mathrm{a}$, and correlations of the signal at $\delta 6.38(\mathrm{H}-2)$ with $\mathrm{C}-1, \mathrm{C}-3, \mathrm{C}-$ 4 and $\mathrm{C}-9 \mathrm{a}$, and that of a methoxy signal at $\delta 3.90$ (3$\mathrm{OCH}_{3}$ ) with $\mathrm{C}-3$ allowed an unequivocal assignment of ring $\mathrm{A}$ in the xanthone moiety. In ring $\mathrm{B}$, the correlation of the signal at $\delta 11.33(8-\mathrm{OH})$ with $\mathrm{C}-8, \mathrm{C}-7$ and C-8a; $7.24(\mathrm{H}-$ 6) with $\mathrm{C}-6, \mathrm{C}-7, \mathrm{C}-8$, and the signal at $\delta 6.66(\mathrm{H}-7)$ with C-8, C-8a, (C-5) and C-5 established the free hydroxyl position at $\mathrm{C}-5$ along with the other assignments of ring $\mathrm{B}$. These data established the xanthone substructure of our compound 1 to be related to the xanthone bellidifolin [16], however with a substituent at C-4.

The absence of carbon resonances below $90 \mathrm{ppm}$ suggested the presence of a saturated $\mathrm{C}_{10}$ side chain at C-4. From the twelve degrees of unsaturation, calculated from the formula of $\mathbf{1}$, ten were attributed to the xanthone nucleus and the other two to rings in the side chain. These two rings consist of a 7-oxo-[2.2.1]-system, as determined by ${ }^{1} \mathrm{H}-{ }^{1} \mathrm{H}$ COSY and HMBC spectroscopy (Fig. 2). This was further confirmed by comparison of the NMR data with those of the 7-oxo-[2.2.1]-system in the related parvixanthone I [17]. The C-14/C-15/C-16 connectivity was deduced from the ${ }^{1} \mathrm{H}-{ }^{1} \mathrm{H}$ COSY cross-peaks between $\mathrm{H}-14 / \mathrm{H}-15$ and $\mathrm{H}-15 / \mathrm{H}-16$. From this partial structure, the six-membered ring from $\mathrm{C}-12$ to $\mathrm{C}-17$ could be confirmed from the following HMBC correlations: Me-19/C12,13,17,20; Me-20/C-12,13,17,19; and Me-21/C-12,16,17. The $\mathrm{C}-14$ and $\mathrm{C}-17$ positions were further deduced to be connected by an oxygen bridge (O-18) by the important HMBC correlation of $\mathrm{H}-14 / \mathrm{C}-17$ and the fact that both C$14(\delta$ 86.9) and C-17 ( $\delta$ 87.7) were oxygenated. Thus, a

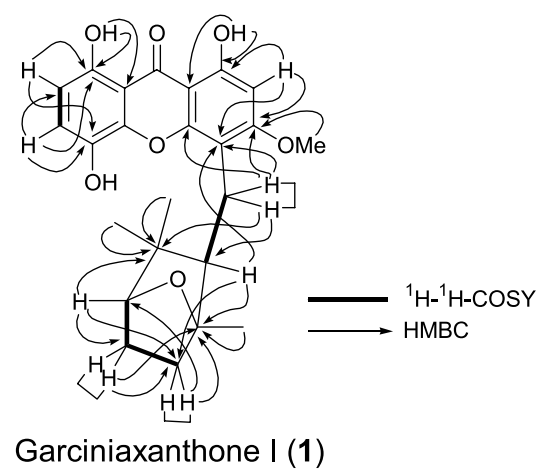

Fig. 2 Selected ${ }^{1} \mathrm{H}^{-1} \mathrm{H}$ COSY and $\mathrm{HMBC}$ correlations for compound $\mathbf{1}$.

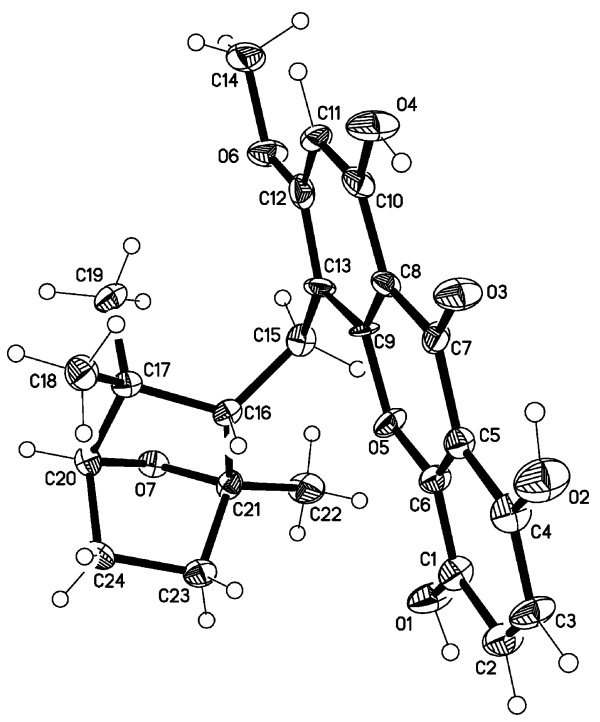

Fig. 3 Molecular structure of $\mathbf{1}$.

Ellipsoids are drawn at the 50\% probability level. 


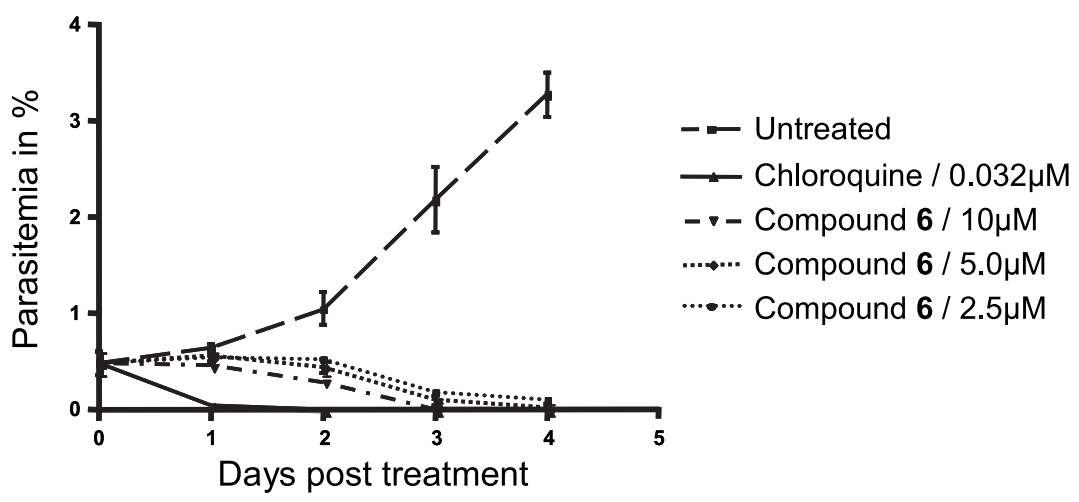

Fig. 4 Antiplasmodial activity of compound $\mathbf{6}^{\text {a }}$.

${ }^{a}$ Growth curves of $P$. falciparum strain NF54 after treatment with different concentrations of compound $\mathbf{6}$ are shown. Inhibitor treatment was started at a parasitemia of $0.5 \%$ and monitored for 96 hours.

monoterpenoid substitution in $\mathbf{1}$ was determined as a 7oxo-[2.2.1]-system, which was linked to position C-4 of the xanthone nucleus, as indicated by the HMBC correlations between H-11/C-4,3,4a. Finally, the detailed structure and relative stereochemistry of $\mathbf{1}$ were confirmed unambiguously from single-crystal X-ray analysis (ORTEP drawing in Fig. 3). Compound 1 was given the trivial name garciniaxanthone I, and assigned as 1,5,8-trihydroxyl-3methoxy-4-(1,3,3-trimethyl-7-oxabicyclo[2.2.1]hept-2ylmethyl)xanthone.

Compound 2 was obtained as a white powder. The broad band and DEPT ${ }^{13} \mathrm{C}$-NMR spectra (see Experimental) of garcinane (2) displayed 32 carbon signals comprising of eight quaternary, six methine, ten methylene and eight methyl carbons. The carbonyl of the ester moiety resonated at $\delta 172.4\left(\mathrm{CH}_{3} \mathrm{CO}_{2}\right)$ while the olefinic carbons were observed at $\delta 144.3$ (C-13) and 122.1 (C-12). Three oxygenated carbons resonated at $\delta 84.4$ (C-3), 67.6 (C-2), and 69.7 (C-28). In the ${ }^{1} \mathrm{H}-\mathrm{NMR}$ spectrum (see Experimental), signals were observed for one olefinic proton at $\delta 5.20(\mathrm{t}, J=4.0 \mathrm{~Hz})$, two oxymethine protons [ $\delta$ 4.51 (d, $J=10.0 \mathrm{~Hz}$ ), 3.80 (ddd, $J=12.5,10.0,4.5 \mathrm{~Hz}$ )], an $\mathrm{AB}$ system of methylene protons on a carbon bonded to an oxygen at $\delta 3.53(\mathrm{~d}, J=10.0 \mathrm{~Hz})$ and 3.80 (ddd, $J=12.5$, $10.0,4.5 \mathrm{~Hz})$, seven tertiary methyl groups $(\delta 0.87,0.88$, $0.89,0.90,0.94,1.01$, and 1.16), and one acetate methyl singlet at $\delta 2.14$. The attachment of the acetate group at C-3 $(\delta$ 84.9) was confirmed by long-range correlation between $\mathrm{H}-3$ and the carbonyl group at $\delta 172.4\left(\mathrm{CH}_{3} \mathrm{CO}_{2}\right)$. On the basis of the molecular formula and NMR $\left({ }^{1} \mathrm{H}-,{ }^{12} \mathrm{C}-\right.$ NMR) data analysis [C-12 (122.1) and C-13 (C-144.3) in ${ }^{13} \mathrm{C}$-NMR], and an intense fragment ion peak at $\mathrm{m} / \mathrm{z} 203$ it was concluded that compound $\mathbf{2}$ was an $\Delta^{12}$-oleanane-type triterpene [18 20]. From the ${ }^{1} \mathrm{H}-\mathrm{NMR}$ data it was concluded that the $\mathrm{OH}$ groups at positions $\mathrm{C}-2$ and $\mathrm{C}-3$ must be equatorial, since the coupling constants of $\mathrm{H}-2$ $\left(J_{2 \mathrm{ax}, 1 \mathrm{ax}}=12.5, J_{2 \mathrm{ax}, 3 \mathrm{ax}}=10 \mathrm{~Hz}\right)$ and $\mathrm{H}-3\left(J_{3 \mathrm{ax}, 2 \mathrm{ax}}=10 \mathrm{~Hz}\right)$ were consistent with axial configurations for both protons. The $2 \alpha, 3 \beta$ relative configuration was further confirmed by comparison of the ${ }^{1} \mathrm{H}$-NMR coupling constants with those reported for related compounds [21, 22]. The hydrolysis of 2 with $\mathrm{K}_{2} \mathrm{CO}_{3}$ in $\mathrm{MeOH}$ at room temperature afforded $2 \alpha$-hydoxyerythrodiol [23]. Therefore, garcinane (2) was assigned as a new compound, $3 \beta$-O-acetyl- $2 \alpha$ hydroxyolean-12-en-28-ol.

Smeathxanthone A (3) and B (4) [3], chefouxanthone (5) [24], isoxanthochymol (6) [5], magnificol [25], and $\beta$ sitosterol [26] were identified by comparison with published data.

\section{Biological Activity}

Compounds $\mathbf{1} \sim \mathbf{6}$ were tested against Plasmodium falciparum in vitro. Among these compounds, 6 showed good activity against Plasmodium falciparum in vitro and less so for compounds $\mathbf{1} \sim \mathbf{5}$. Compound $\mathbf{6}$ exhibited antimalarial activity with an $\mathrm{IC}_{50}$ of $2.21 \mu \mathrm{M}$ (Fig. 4). This was lower than the $\mathrm{IC}_{50}$ of the other five compounds, which ranged from $2.5 \sim 4.1 \mu \mathrm{M}$.

In summary, the structure of a new xanthone (1) with the very rare cyclization of a geranyl residue to a 7-oxo[2.2.1]-system was elucidated and confirmed by X-ray single crystal analysis. The entire set of prenylated xanthones $\mathbf{1}$ and $\mathbf{3} \sim \mathbf{6}$ showed a remarkable variety in attachment and cyclization modes of prenyl and geranyl side chains thus increasing the diversity of this class of plant metabolites. In addition, the in vitro activity against Plasmodium falciparum of isoxanthochymol (6) with an interesting bridged ring system was established. 
Acknowledgement A. Meli Lannang thanks DAAD for a postdoctoral fellowship at the University of Paderborn, Germany and TWAS Research Grand N ${ }^{\circ}$ 05-148 RG/CHE/AF/AC.

\section{References}

1. Kanda P, Pongcharoen W, Phongpaichit S, Walter CT. Tetraoxygenated xanthones from the fruits of Garcinia cowa. Phytochemistry 67: 999-1004 (2006)

2. Deachathai S, Mahabubarakam W, Phongpaichit S, Taylor WC, Zhang YJ, Yang CR. Phenolic compounds from the flowers of Garcinia dulcis. Phytochemistry 67: 464-469 (2006)

3. Komguem J, Meli AL, Manfouo RN, Lontsi D, Ngounou FN, Kuete V, Kamdem WH, Tane P, Ngadjui BT, Sondengam BL, Connelly JD. Xanthones from Garcinia smeathmannii (Oliver) and their antimicrobial activity. Phytochemistry 66: 1713-1717 (2005)

4. Rukachaisirikul V, Adair A, Dampawan P, Taylor WC, Turner PT. Lanostanes and friedolanostanes from the pericarp of Garcinia hombroniana. Phytochemistry 55: 183-188 (2000)

5. Nilar LH, Nguyen D, Ganpathi V, Sim KY, Harrison LJ. Xanthones and benzophenones from Garcinia griffithii and Garcinia mangostana. Phytochemistry 66: 1718-1723 (2005).

6. Williams RB, Hoch J, Glass TE, Evans R, Miller JS, Wisse JH, Kingstone DGI. A Novel Cytotoxic Guttiferone Analogue from Garcinia macrophylla from the Suriname Rainforest. Planta Med 69: 864-866 (2003)

7. Ampofo AS, Waterman GP. Xanthones from three Garcinia species. Phytochemistry 25: 2351-2355 (1986)

8. Brehaut J. Flore illustré du Sénégal. Gouvernement du Sénégal, ministère du développement rural et de l'hydraulique, direction des eaux et forêt, Dakar, pp. 89-90 (1975)

9. Bruker. SMART (Version 5.62), SAINT (Version 6.02). Bruker AXS Inc., Madison, Wisconsin, USA (2002)

10. Sheldrick, G. M. A short history of SHELX. Acta Cryst A64: 112-122 (2008)

11. Andrade-Neto VF, Goulart MOF, Filho JFS, Silva MJ, Pinto MCFR, Zalis MG, Carvalho LH, Krettli AU. Antimalarial activity of phenazines from lapachol, $\beta$-lapachone and its derivatives against Plasmodium falciparum in vitro and Plasmodium berghei in vivo. Bioorg Med Chem Lett 14: 1145-1149 (2004)

12. Moloney MB, Pawluk AR, Ackland NR. Plasmodium falciparum growth in deep culture. Trans R Soc Trop Med Hyg 84: 516-518 (1990)

13. Trager W, Williams J. Extracellular (axenic) development in vitro of the erythrocytic cycle of Plasmodium falciparum. Proc Natl Acad Sci USA 89: 5351-5355 (1992)

14. Singh S, Puri SK, Singh SK, Srivastava R, Gupta RC, Pandey VC. Characterization of Simian Malarial Parasite (Plasmodium knowlesi)-induced Putrescine Transport in Rhesus Monkey Erythrocytes. J Biolog Chem 272: 13506-13511 (1997)

15. Meli AL, Komguem J, Ngounou FN, Tangmouo JG, Lontsi D, Ajaz A, Choudhary MI, Ranjit R, Devkota KP, Sondengam BL. Bangangxanthone A and B, two xanthones from the stem bark of Garcinia polyantha Oliv. Phytochemistry 66: 2351-2355 (2005)

16. Markan KR. Gentian pigments-II: Xanthones from Gentiana bellidifolia. Tetrahedron 21: 1449-1452 (1965)

17. Xu JY, Lai YH, Imiyabir Z, Goh SH. Xanthones from Garcinia parvifolia. J Nat Prod 64: 1191-1195 (2001)

18. Mathe C, Culioli G, Archier P, Vieillescazes C. Characterization of archaeological frankincense by gas chromatography-mass spectrometry. J Chromatogr A 1023: 277-285 (2004)

19. Nicollier G, Thompson AC. A new triterpenoid saponin from the flowers of Melilotus alba, white sweet clover. J Nat Prod 46: 183-186 (1983)

20. Doddrell DM, Khong PW, Lewis KG. The stereochemical dependence of ${ }^{13} \mathrm{C}$ chemical shifts in olean-12-enes and urs12-enes as an aid to structural assignment. Tetrahedron Lett 27: 2381-2384 (1974)

21. Leo MD, Tommasi ND, Sanogo R, D'Angelo V, Germano MP, Bisignano G, Braca A. Triterpenoid saponins from Pteleopsis suberosa stem bark. Phytochemistry 67: 2623-2629 (2006)

22. Mencherini T, Picerno P, Scesa C, Aquino R. Triterpene, antioxidant, and antimicrobial compounds from Melissa officinalis. J Nat Prod 70: 1889-1894 (2007).

23. Granados G, Lopez EP, Melguizo E, Moliz JN, Parra A, Simeo Y. Epoxides, cyclic sulfites, and sulfate from natural pentacyclic triterpenoids: theoretical calculations and chemical transformations. J Org Chem 68: 4833-4844 (2003)

24. Meli AL, Komguem J, Tangmouo JG, Lontsi D, Ngounou FN, Ajaz A, Choudhary MI, Sondengam BL, Rhaman A. Antioxidant benzophenones and xanthones from the root bark of Garcinia smeathmannii. Bull Chem Soc Ethiop 20: 247-252 (2006)

25. Castelli F, Sarpietro MG, Micieli D, Trombetta D, Saija A. Differential scanning calorimetry evidence of the enhancement of $\beta$-sitosterol absorption across biological membranes mediated by $\beta$-cyclodextrins. J Agric Food Chem 54: 10228-10233 (2006)

26. Rubinstein I, Goad LJ, Clague ADH. The $220 \mathrm{MHz}$ NMR spectra of phytosterols. Phytochemistry 15: 195-200 (1976) 